\title{
The pattern of disorders of sex development in Vietnamese children
}

\author{
Pham Thu Nga ${ }^{*}$, Vu Chi Dung ${ }^{2}$, Bui Phuong Thao ${ }^{2}$, Nguyen Ngoc Khanh², Can Thi Bich Ngoc ${ }^{2}$, \\ Hoan Nguyen Thi ${ }^{2}$, Dat Nguyen $\mathrm{Phu}^{2}$ \\ From 8th APPES Biennial Scientific Meeting \\ Darwin, Australia. 29 October - 1 November 2014
}

\section{Background}

Disorders of sex development (DSD) are defined as congenital condition in which development of chromosomal, gonadal, or anatomical sex is atypical. The Chicago DSD classification includes three main diagnostic categories: sex chromosome DSD, 46,XY DSD and 46,XX DSD.

\section{Aims}

Define the pattern of disorders of sex development according to Chicago's classification 2006 at National Hospital of Pediatrics in Hanoi, Vietnam (NHP).

\section{Method}

Patients were examined, diagnosed and treated DSD or ambiguous sex at (NHP) from 31/07/2002 to 31/7/2012. Criteria that suggest DSD include

1. overt genital ambiguity (eg, cloacal exstrophy)

2. apparent female genitalia with an enlarged clitoris, posterior labial fusion, or an inguinal/labial mass

3. apparent male genitalia with bilateral undescended testes, micropenis, isolated perineal hypospadias, or mild hypospadias with undescended testis

4. a family history of DSD such as CAIS, and

5. a discordance between genital appearance and a prenatal karyotype. Method of the study was descriptive observational.

\section{Results}

51.7\% patients had 46,XX DSD, among them 98.6\% had definitive diagnosis. Congenital adrenal hyperplasia (CAH) is the most common cause of $46, \mathrm{XX}$ DSD (91.9\%). Rate of $46, \mathrm{XY}$ DSD was $25 \%$, however $83.3 \%$

${ }^{1}$ Hanoi Medical University, Hanoi, Vietnam

Full list of author information is available at the end of the article had no definitive diagnosis. $23.3 \%$ of patients had chromosome DSD, among them $88.3 \%$ chromosome DSD was Turner syndrome.

\section{Conclusion}

$\mathrm{CAH}$ is the most common cause of DSD.

\section{Authors' details \\ ${ }^{1}$ Hanoi Medical University, Hanoi, Vietnam. ${ }^{2}$ Vietnam National Hospital of Pediatrics, Hanoi, Vietnam.}

Published: 28 April 2015

\section{doi:10.1186/1687-9856-2015-S1-P115}

Cite this article as: Nga et al:: The pattern of disorders of sex

development in Vietnamese children. International Journal of Pediatric Endocrinology 2015 2015(Suppl 1):P115.

Submit your next manuscript to BioMed Central and take full advantage of:

- Convenient online submission

- Thorough peer review

- No space constraints or color figure charges

- Immediate publication on acceptance

- Inclusion in PubMed, CAS, Scopus and Google Scholar

- Research which is freely available for redistribution 